\title{
An Emergent Sense of the Literary: Doing Children's Poetry Translation in the Literature Classroom
}

\author{
Un sentido incipiente de lo literario: hacer traducción de poesía \\ infantil en el aula
}
Un sentit incipient d'allò literari: fer traducció de poesia infantil a l'aula

\author{
Clementine Beauvais. University of York, clementine.beauvais@york.ac.uk
}

https://orcid.org/0000-0002-5854-4866

\begin{abstract}
This article brings together findings from translation theory, the poetics of children's poetry, and the pedagogy of translation, in an attempt to theorise the practice of poetry-translation in the literary, first-language classroom. I argue that translating children's poetry in the context of translation workshops mobilises skills, and encourages ways of thinking about poetry, that espouse particularly well one of the complex challenges of literary education: namely, triggering in learners an emergent sense of the literary. Poetry-translation, I contend, allows for profoundly experiential engagement with some of the most sophisticated, and least easily articulated, aspects of the aesthetics of literature - prominently, the resistance of the literary text to paraphrase, the lack of a clear content-form dichotomy, and the embodied aspects of the literary encounter. Because translating is never just writing, but always already writing one's reading, the translation of poetry in the literary classroom requires pupils to capture, experience, and take ownership of their encounters with literature, in order to re-express them. I first explain the practice of literary translation in the classroom; I then talk about contemporary poetry translation theory and its deeply phenomenological approach to text. I next show why the particular poetics of children's poetry situate that kind of text ideally for a pre-semantic, intuitive approach to poetry translation. Finally, I look at the writing process as a way of turning the pupil into what Roland Barthes calls a poéticien, a person whose poetry-writing does theoretical work.
\end{abstract}

Keywords: children's poetry, translation, literary education, aesthetics

\section{Resumen}

Este artículo recoge resultados desde la teoría de la traducción, la poética de la poesía infantil y la pedagogía de la traducción en un intento de teorizar la práctica de la traducción de poesía en el aula de literatura de L1. Se argumenta que la traducción de la poesía infantil en el contexto de los talleres de traducción, activas destrezas e incentivas maneras de pensar acerca de la poesía que apoya especialmente bien uno de los complejos retos de la educación literaria, concretamente 
desencadenar en los y las aprendices un incipiente sentido de lo literario. La traducción de poesía, se defiende, permite un compromiso experiencial profundo con algunos de los más sofisticados y menos fácilmente articulados, aspectos de la estética de la literatura. De manera prominente, la resistencia del texto literario a la paráfrasis, la falta de una dicotomía clara forma-contenido y los aspectos integrantes del encuentro literario. Porque la traducción nunca es solo escribir sino siempre haber escrito la propia lectura, la traducción de poesía en el aula de literatura requiere que el alumnado capture, experiencie y se apropie de sus encuentros con la literatura para re-expresarlos. Primero se explica la práctica de la traducción literaria en el aula; después se habla sobre la poesía contemporánea y su enfoque profundamente fenomenológico. Después se muestra por qué la particular poética de la poesía infantil sitúa este tipo de texto idealmente para un enfoque presemántico, intuitivo de la traducción de la poesía. Finalmente, se observa el proceso de escritura como una manera de convertir el alumnado en lo que Roland Barthes llama un poéticien, una persona cuya escritura poética realiza un trabajo teórico.

Palabras clave: poesía infantil, traducción, educación literaria, estética

\section{Resum}

Aquest article arreplega troballes des de la teoria de la traducció, la poètica de la poesia infantil i la pedagogia de la traducció en un intent de teoritzar la pràctica de la traducció de poesia en l'aula de literatura de L1. S'argumenta que la traducció de la poesia infantil en el context dels tallers de traducció activa destreses i encoratja maneres de pensar al voltant de la poesia que dona suport especialment bé a un dels complexos reptes de l'educació literària: concretament desencadenar en els/les aprenents un incipient sentit d'allò literari. La traducció de poesia, es defèn, permet un compromís experiencial profund amb alguns dels més sofisticats i menys fàcilment articulats, aspectes de l'estètica de la literatura. De manera prominent, la resistència del text literari a la paràfrasi, la manca d'una dicotomia clara forma-contingut i els aspectes integrants de l'encontre literari. Perquè la traducció mai és només escriure sinó sempre haver escrit la pròpia lectura, la traducció de poesia a l'aula de literatura requereix que l'alumnat capture, experiencie i s'apropie dels seus encontres amb la literatura per tal de re-expressar-los. Primer s'explica la pràctica de la traducció literària a l'aula; després es parla sobre la poesia contemporània i el seu enfocament profundament fenomenològic. Després es mostra per què la particular poètica de la poesia infantil situa aquest tipus de text idealment per a un acostament presemàntic, intuïtiu de la traducció de la poesia. Finalment s'observa el procés d'escriptura com a una manera de convertir l'alumnat en allò que Roland Barthes anomena a poéticien, una persona l'escriptura poètica de la qual fa un treball teòric.

Paraules clau: Poesia infantil, traducció, educació literària, estètica. 


\section{Introduction}

This article seeks to theorise the translation of children's poetry for the purpose of literary education, in the first-language classroom. Literary translation in the classroom is underresearched, but particularly so as a way of teaching literature. Translation tends to be seen as the preserve of foreign language teaching, where it is principally done for its benefits regarding language acquisition, and rarely for its potential to acquaint language-learners with foreign literature, or with the devices, poetics, rhetoric, metaphorical imagination, etc. of the other language. Even then, poetry is an infrequent choice of source text, perhaps due to a common (mis)perception of poetry as untranslatable. In literary education, practices of literary translation, let alone poetry translation, are rarer still.

Yet I am arguing here for poetry translation in education, not for second-language learning, but

The complex demands of poetry translation require, and potentially sharpen, a particular sensitivity to what constitutes 'the literary' that elusive sense that a cluster of words rings like it was composed for aesthetic gratification within the first-language literature class, as a powerful tool for the emergence of what I shall for now call a sense of the literary in young learners. Poetry translation, perhaps the type of translation most characterised by its resistance to literalism, forces the young translator into an experience of the literary text that goes beyond the semantic and the analytical. It engages pupils with the decisions routinely taken by professional poetry translators, informed partly by close reading, contextual knowledge and linguistic skill, but also by intuition, sensibility to sound and rhythm, performance, taste, attention to effect, no small amount of frustrated resignation, and the occasional epiphany. The complex demands of poetry translation require, and potentially sharpen, a particular sensitivity to what constitutes 'the literary' - that elusive sense that a cluster of words rings like it was composed for aesthetic gratification.

In this paper I focus especially on the translation of children's poetry, and look at how that practice can be deployed within literary translation workshops (mostly in primary schools here, but there is ample space for similar theorisation and practices in higher years). I present the practice of literary translation workshops in a first subpart. I then turn to the translation of poetry, in its conceptualisation by translation theorists as a phenomenological reading of poetry. This should encourage educators to view translating as a species of experiential learning, a practice that does theoretical work of its own; thus, translating poetry is, I argue, always already a way of knowing poetry. Next, I discuss why children's poetry may be a particularly fruitful source text, drawing upon recent theoretical work on its poetics. Finally, I theorise the 
translation-writing itself, which registers - with necessary compromise - the translator's multifaceted engagement with those poetics.

I hope eventually to reclaim the worth, for literary education, of those moments where there are no words, or there is an excess of signification that cannot be named but can be felt. The necessary imperfection of poetry translation makes it impossible to ignore that poetic texts resist paraphrase, engage the whole body, are lived in space and time, and are framed by human relationships. Those characteristics are at the heart of poetics and, arguably, of any literature worthy of the name. Being made to experience them, I argue, has pedagogical as well as aesthetic value.

\section{Literary translation in schools: an overview}

Practices of collaborative literary translation in educational or para-educational contexts are varied and ill-mapped; I summarise them here with the understanding that any such overview in the current research landscape is necessarily non-exhaustive.

Translation workshops with aspiring translators have been a staple of training since the increased professionalisation of translation, from the 1980s onwards (Venuti 2000). But practices of translation in education are, of course, older: translation was always, in the West, a key way of studying ancient languages and literature (Houdart-Mérot 2018, 11). Today, translation is still part of second-language curricula in some countries - notably in France, where the bicephalous exercise of thème and version (translation into and out of the second language) has a rigorous grid of assessment criteria, with quantifiable punishment for barbarisms, solecisms, calques and other unforgivable 'mistranslations' (Bastin 2007). In the UK, translation has made a comeback in the GCSE foreign language examinations (taken by students aged 16), though the texts are not literary, and the translations evaluated solely for semantic accuracy.

From a theoretical perspective, those approaches are dissonant with current translation studies, which, following poststructuralism, have developed conceptual frameworks allowing for nonevaluative analysis, thick description, deconstruction; attention to the material conditions of translation; and receptiveness to the contextually-negotiated aims of translation projects (see Venuti 1998 and 2000; Davis 2001; Bassnett 2004; Munday 2009). There is a philosophical chasm between contemporary advances in translation theory and visions of translation in the classroom today.

Other initiatives, however, have sprouted worldwide to bring literary translation to pupils; among which literary translation workshops or exercises, initiated by teachers or translators. 
Most take place in second-language or plurilingual classes, with practices inscribed within foreign language pedagogy and intercultural competence (Greaves and Schultze 2012a and 2017; Jiménez et al. 2015; Dompmartin-Normand 2016; Brookman and Robinson 2016; Kultti \& Pramling 2018). But literary translation workshops are also being developed for wider purposes. In the UK, two charities - Translators in Schools and Shadow Heroes - provide training programmes for professional translators and deploy translators in primary and secondary schools. In the US, one programme, Poetry Inside Out, has since 2000 offered poetry translation workshops, pedagogical packs, and teacher-training (Rutherford 2009). Some translators also lead such workshops independently from early years to high school and with adults, in schools, book fairs, libraries, cultural centres, etc. There are some case studies and reports on the structures, methods and benefits of the practice (Reece et al 2013; Nichols 2014; Park 2015; Park et al, 2015; Holmes 2015a and 2015b; Lathey 2016; Beauvais 2018b; Stephen Spender Trust 2019). While many different approaches exist, the literature allows us to register a number of constants, which I present now.

Most literary translation workshops offer students the opportunity to translate text from a foreign language into the students' own (native or near-native) language. The exercise is designed so as not to require knowledge of the source language $(\mathrm{SL})$ of the text; rather, the students' expertise in the target language (TL) is stressed as the key skill.

Working from that assumption, a translation workshop typically involves the following elements:

- Encounter with the foreign text in the SL. The text might be read out loud by the workshop leader, or presented written-out, potentially phonetically. The semantic meaning is generally not clarified straightaway; rather, analysis of sounds, rhythms, etc., can generate hypotheses regarding tone or genre.

- Semantic investigation. Collaboratively or individually, with glossaries, dictionaries, the Internet, through guesswork, or asking the workshop leader, students cobble together a basic literal understanding of the text.

- Creative reformulation (literary translation proper). The students then rework the 'semantically correct' draft into a literary text. Poetry Inside Out call this the 'make-it-flow' translation (Park 2015a, p.136).

- Sharing and group discussion. The workshop generally ends after a read-aloud of the translations and comparative, rather than evaluative, discussion of the decisions. 
While such exercises are not equivalent to a professional translator's work (Jiménez et al 2015, 252), they do espouse those contours more closely than translation exercises of the thème / version type. Their premises align with current translation scholarship, which sees the practice as more dependent on the translator's fluency and creativity in the TL than their mastery of the SL (e.g. see Grossman 2010, 72). They also use the typical direction of professional literary translation (from L2 into L1). Furthermore, such workshops in their structure and outcomes tend to challenge the idea that there are 'correct' ways of translating; to inscribe semantics within wider processes of meaning-making; and to give the translator, implicitly and explicitly, authorial ownership. They are de facto more attentive to readability and creativity of the translated text than duty-bound to the formal parameters of the source text (in translation studies terminology: they are more target-oriented than source-oriented).

Having described the typical literary translation workshop, I step slightly aside to look at theorisations of poetry translation. As I hope to show, there are solid conceptual foundations for educational thinkers to envisage the practice of poetry translation in the classroom as an experiential approach to the literary.

\section{Poetry translation as a phenomenology of poetry-reading}

The translation of poetry is relatively little-practiced, because it is commercially unviable, but it is abundantly theorised, because it is intellectually captivating. Poetry translation magnifies some of the most complex problems of general translation theory, and links them to aesthetics. Where the pamphlet or journalistic sob story aim, like the literary text, at the elicitation of emotional gratification (including, of course, cathartic gratification derived from 'negative' emotions, of disgust, anger, sadness, etc.), the literary text is aesthetic insofar as, arguably, it sublimates that emotional gratification into an experience of the beautiful.

It is far beyond this article to summarise conceptualisations of literary aesthetics; but one that interests me here is the question of literature's resistance to paraphrase. Literary language is often seen as resisting intralinguistic translation, which linguist Roman Jakobson (1959) distinguishes from

The translation of poetry is relatively littlepracticed, because it is commercially unviable, but it is abundantly theorised, because it is intellectually captivating. Poetry translation magnifies some of the most complex problems of general translation theory, and links them to aesthetics. interlinguistic and intersemiotic translation. Intralinguistic translation refers to reformulation using other words - e.g. 'I called you but you 
didn't pick up' might become 'I phoned you but you didn't answer'. For discourse whose function is primarily informative, intralinguistic reformulation tends to be straightforward, and routinely practiced. Such messages are also fairly unproblematically subjected to interlinguistic translation.

The possibility for paraphrasing, rephrasing, and therefore translating, is more complex for literary or persuasive utterances (what Katharina Reiss, 1971, calls the expressive and operative functions of language). Such language indeed typically works by unsettling linguistic conventions. Words might be used outside of their habitual referential relationship (as with metaphor). Sentence constructions might twist or contravene conventional syntax, as with zeugmas, chiasmus, or intentional sentence fragments. Other work may occur on acoustics, musicality, rhythm, pacing, in the composition - e.g. alliteration, assonance, rhyme, metrical patterns, ellipsis, etc. - thus manœuvring the recipient's attention towards salient moments in the text, and seeking sensory gratification.

That composition process makes it futile to talk for literature of distinctions between form and content. It is not that the writer 'selects' features to 'fit' a content; rather, a text emerges as expressive or persuasive when there is no other way to put it. This is all the clearer in poetry, where attention to composition is at its most intense. As Roland Barthes suggests $(1984,13)$, building on Jakobson, poetry attracts the reader's attention to the fact of its own artificiality; its form is the focus, and its primary communicative value is its own artistry. We can of course analyse literature - or else, the whole hermeneutics of literary studies would be void. We can expand on a literary text in a literary way - through rewritings, pastiche, parody, etc. However, the proposition to reformulate, or intralinguistically translate, in a literary way, a literary text is, in theory, untenable.

Yet such is the premise of interlinguistic poetry translation. For it to exist, it must be possible, somehow, for poems in one language to be rewritten - re-expressed - in another. How can something that is intralinguistically unavailable be interlinguistically possible? Some thinkers argue it cannot. Poetry is widely perceived as the outer limit of translatability, especially haunted by that sense of loss that George Steiner called the 'special miseria of translation' $(1975,269)$, and Percy Bysshe Shelley 'the burden of the curse of Babel', in his vitriolic attack against the 'vanity of [poetry] translation' (1821). Poetry translation has long been cloaked in a mystique of impossibility (Ricoeur, 2004), luring some poets into ambitious attempts, and plunging others into elitist despair - (in)famously Vladimir Nabokov, with his literal translation of Pushkin's Eugene Onegin (Nabokov 1955; see also Jones 2011). 
Contemporary theories of poetry translation, however, rarely take seriously such assertions; they focus, instead, on operations by which poetry translation is possible (Boase-Beier 2013). André Lefevere proposes seven strategies, not all of them qualitatively equivalent (1975). One of the most basic operations is literal translation, which he argues cannot lead to a work of art; the most satisfactory is the creation of a comparably aesthetic poem, attuned to the poetics of the target language. Susan Bassnett stresses the merits of pleasure: 'what matters in the translation of poetry is that the translator should be so drawn into the poem that he or she then seeks to transpose it creatively, through the pleasure generated by the reading' $(1988,74)$. Translating a poem means experiencing the aesthetic pull of the poem.

Translators aptly express the exercise's contradictory demands. 'Translating: the worry worry worry over the difference between this word and that, the weight and angle and sound and even the taste of this word over that', says Kate Briggs $(2017,189)$. 'The laws of reading, understanding, translating a poem are not simple and that perhaps we must lose in the beginning in order to be able later to recover more fully', adds Yves Bonnefoy $(1979,375)$. Emily Wilson, the author of a recent translation of Homer's Odyssey, notes her 'different responsibilities: to the original text; to my readers; to the need to make sense; to the urge to question everything; to fiction, myth, and truth; to the demands of rhythm and the rumble of sound; to the feet that need to step in five carefully trotting paces, and the story that needs to canter on its way' $(2017,90)$. Not coincidentally, those demands sound similar to those of creative writing. Translating poetry, in short, is writing poetry.

Yet it is not just writing poetry; it is also reading poetry, and, a proposition more puzzling still, writing one's reading of poetry. 'Translation is the most intimate act of reading,' says Gayatri

Translating poetry, in short, is writing poetry. Yet it is not just writing poetry; it is also reading poetry, and, a proposition more puzzling still, writing one's reading of poetry.
Chakravorty Spivak (1992, 400); not just because it requires close analysis of text, but because it involves letting oneself 'surrender' to the text (id.). Clive Scott's formidable 'metabolic' project (2012) envisions the translation of poetry, drastically elasticated, as a species of experimental writing, codependent with a particular reading philosophy and interpretive practice. In Scott's view, the translatorpoet encounters - absorbs, even - the source text, always contextually, and brings their own history to it; the translation will re-express, not so much 'the text' (never a fixed thing), but the reading experience. Because that experience is multifarious, so the translation must be; Scott's productions are joyfully transmedial and multimodal. Potentially endless and unbound, the translation process involves writing, but also 
spatialisation, visuals, performance, voice; in short, an interlinguistic but also always-already intersemiotic approach. Thus Scott writes his reading, rather than write about his reading, or rewrite the text. His approach supports the idea, influential in contemporary translation theory, that poetry translation encodes not just a text but a literary experience.

Such practices of poetry translation do theoretical work of their own: they reclaim the phenomenological aspects of reading poetry, by seeking to be a phenomenology of poetryreading. As such, the poetics of translated poetry draw attention, not just to the artificiality of the composition itself, but to what that artificiality expresses of the reading experience of the source text. Therefore poetry translation shares some of its characteristics with rewriting, pastiche, etc.; namely, texts which also 'write readings'. I mention this because it helps understand why poetry translation might have value from the perspective of literary education: creative writing exercises already often take intertextuality as their prompt ('write in the manner of'), nudging learners towards rewriting. With such prompts, the creation registers not just the learner's scholarly understanding of the master text, but, importantly, their reading experience of it. While 'write an essay on Shakespeare's sonnets' seeks to elicit analytical reflection about the sonnets, the prompt 'write a sonnet in the manner of Shakespeare' seeks to register an experiential reading of the sonnets. Analysis, in the latter case, is not absent, but it is one of several aspects of reading mobilised by the exercise.

To a degree, the translation of poetry is a 'write in the manner of' prompt; where it differs (Scott might retort that it does not) is that it requires bringing together two languages, and constantly reflecting about the spaces in-between. That zone, what sinologist Francois Jullien calls the écart, the gap, is where friction between two cultures occurs, in its linguistic, sociocultural, political, and of course aesthetic, dimensions (Jullien 2012; Beauvais 2018a). That friction is expressed by language just as it expresses it; and it modulates reading experiences across the gap. Thus, in the interlinguistic process central to translation, one can, and arguably should, experience constant oscillation within that contact zone. Writing in the [...] creative writing exercises already often take intertextuality as their prompt ('write in the manner of'), nudging learners towards rewriting. With such prompts, the creation registers not just the learner's scholarly understanding of the master text, but, importantly, their reading experience of it manner of Shakespeare in another language means processing Shakespeare and one's reading of Shakespeare in that other language. The translation of poetry asks that one encode, in the familiar, the experience of reading the foreign - which Paul Ricoeur $(2004,32)$ pinpoints as a central reason for the 'desire to translate'. 
Having delineated the tight connection between translating poetry and reading poetry - in the experiential sense of reading - I turn to what children's poetry might particularly offer as a source text.

\section{Children's poetry as ideal source text for experiential translation}

Poetry-translation workshops can of course use poetry written 'for adults'; I might ask a French class to translate a sonnet by Shakespeare. With enough guidance, the exercise can produce fascinating outputs and avail the kind of phenomenological encounter with Shakespeare that any educator would wish for. Here, however, I highlight the characteristics of children's poetry that might especially trigger, during the translation process, an experiential understanding of the literary.

The most pragmatic argument for children's poetry as source text is, ironically, its low status. Poetry is omnipresent in children's lives, from nursery rhymes to playground tunes through to verse picturebooks. Yet children's poetry suffers from the double stigma of being not quite children's literature, and not quite poetry (Pullinger 2017). Many such texts are unwritten, anonymous, shape-shifting, ever-repurposed, hostages to memory - that is, alive. But little respect means more playfulness, more leeway to tweak, stretch and break the text. That is precisely what any translator must do; and it is easier to feel allowed when one's translation is a victimless crime. Who's going to be twisting in their grave if you ruin 'Twinkle, Twinkle, Little Star' with your starchy French? Meanwhile, uttering the words 'we are going to translate Shakespeare' might make half a classroom gasp, suddenly conscious of their enormous responsibility for one of humanity's most precious treasures (while the other half yawns, and waits for lunch) (that is, I am aware, an optimistic statistic).

Children's poetry, thus, calibrates a translation process freer from preoccupations about 'faithfulness' than canonical poetry, and thus aligns with contemporary translation theory, which has moved beyond discussions of faithfulness, featuring belles infidèles and traditori; relationships between source and target texts are no longer conceptualised in terms normally reserved for bourgeois marriages (Chamberlain 1985). Yet, literary translation is still folktheorised as such, using a lexicon of surveillance and school-like evaluation, surrounded with suspicion in the public sphere, permanently perceived as a necessary evil for accessing other countries' literature, but always lesser than 'the original' (see Venuti 1988, 90). Anecdotal evidence suggests that even young children already think of translation so; they ask, for instance, if as an author I can 'check' foreign translations of my books. The figure of the author, rightful owner of the work, looms large over this perception, because authorial intention is still 
perceived as an interpretive master key, textually and epitextually sought for. While some children's poets do have authoritative status, children's verse is less weighted by critical and authorial discourse. Thus, the low status of children's poetry, a pity in some respects, is a blessing for translation workshops: here are texts you can play with, as you already do in the playground; don't pretend you haven't already turned this innocent lullaby into something perfectly gross - so there: you are ready, and qualified, to translate it.

I now move to characteristics of children's poetry in aesthetic terms that make its translation in the literature classroom particularly valuable. Until recently,

Thus, the low status of children's poetry, a pity in some respects, is a blessing for translation workshops: here are texts you can play with, as you already do in the playground; don't pretend you haven't already turned this innocent lullaby into something perfectly gross - so there: you are ready, and qualified, to translate it.

and psychology through a poetics of its own; and it is eminently relational. Whether mediated by an adult or shared in social spaces with other children, children's poetry is what Coats called a 'holding' language, which helps children link body and words - the world of concepts and the world of sensations.

This cognitive understanding of children's poetry clicks, I think, with phenomenological understandings of poetry-translation. Both foreground the multifariousness of the poetic, its profoundly experiential nature: the fact that poetic language includes, but also exceeds, semantics, and must be lived in its totality, between 'tongue and text', in Pullinger's terms (2017). If children's encounters with children's poetry routinely makes them experience that totality, and if writing a translation means, partly, registering the experience of encountering text, then the translation of children's poetry is especially well-situated to make young translators sensitive to that total encounter. The complex challenge of encoding that encounter in one's own language will inform a writing process that must involve the whole body. 
Now, I detail some crucial aspects of children's poetry that can help modulate that encounter in a translation workshop.

The first is children's poetry's tendency to be highly alliterative, rhythmically and metrically regular, and performance-based. As children's poetry scholars show, poetry for children often mimics baby talk, singing, chanting, and animal sounds (see Pullinger 2017, 80). This proximity to what could be called a translinguistic soundscape is especially interesting for translation: thanks to it, the emotional makeup of a children's poem in a different language might be picked up on 'accurately' by non-speakers. In practice, this means that a translation workshop in France beginning with a reading of We're Going on a Bear Hunt (Rosen and Oxenbury 1989) can help children unfamiliar with English understand some of the text, without any literal translation: meanings are inferred, rather than revealed. I have italicised, in the extract below, some potential moments of translinguistic understanding through sound:

\author{
We're going on a bear hunt. \\ We're going to catch a big one. \\ What a beautiful day! \\ We're not scared. \\ Uh-uh! Grass! \\ Long wavy grass. \\ We can't go over it. \\ We can't go under it. \\ Oh no! \\ We've got to go through it! \\ Swishy Swashy! \\ Swishy Swashy! \\ Swishy Swashy!
}

Next comes the reading performance: a poem written down is, arguably, a musical score waiting for its instruments, the body and the voice (Cliff Hodges 2016). Gestures can convey extra meaning, again without need for literal translation. Underlined above are potential moments of translinguistic understanding through gestures and performance (many, of course, overlap with sound): illustrating 'going' by marching, 'big' by opening one's arms, etc. Another source of translinguistic understanding is voice, including intonation, volume, exclamations, speed, etc., 
all conveying information regarding, but not limited to, the poem's mood. Facial expressions are other clues. Finally, and obviously, a performance could not occur without picking a rhythmical pattern, drawing attention to the pacing of the text, and to its being poetry. The encounter of, say, French children with the text above, even if they have never heard a word of English, will thus be laden with meaning; much of the mood, narrative movement and main action can be inferred, and the text recognised as poetic, with no resort whatsoever to semantic explanation.

Additional clues, for We're Going on a Bear Hunt and much children's verse, can be gleaned from the visuals. The poem forms half of the narrative of a picturebook; presenting Helen Oxenbury's illustrations alongside the performed text clarifies, to the non-Anglophone child, many other elements, including characters and setting. These are practices well-known to practitioners of second-language teaching specialising in picturebooks (e.g. Mourao 2017) and researchers on the educational potential of wordless picturebooks (e.g. Arizpe, Colomer and Martinez-Roldan 2014). Even without illustrations, a poem's layout provides visual clues as to its subject matter, pacing, speed, and very nature as a poem. Showing the text to the children can therefore contribute to the first intuitive stage of understanding. The visuals will need to be considered, too, during the writing of the translation, because they constrain as well as help the translation. The family will have to go on a bear hunt, not a wolf hunt, or else the ending will be a beast of a narrative twist.

Certainly, an important caveat is that there are no universals in poetics; not all children internationally will interpret cues from the above poem with similar ease. There are profound variations in the translinguistic intelligibility of elements such as sound, structure, rhythm, etc.; variations amply studied by advocates of translanguaging (e.g. Lewis, Jones and Baker 2012). The layout of poems in Roman alphabet, and the letters themselves, will be unknown to children with non-alphabetic languages, and vice-versa. And pictures are far from universally understandable. Those elements should be considered in any translation workshop, but are not major obstacles; they are simply part of the translinguistic and transcultural parameters of the event. It is the workshop leader's responsibility to find ingenious culturally and linguistically graspable adjustments for the first encounter with the poem (a job that can even befall a child speaker of the source language; see Holmes 2015 , 4).

Another benefit of children's poetry for translation workshops is that it is often structurally additive, as Pullinger $(2017,84)$ explains; and narrative poetry uses repetitive, episodic storytelling, evident in We're Going on a Bear Hunt. From the narratology of children's literature, we know that such structures echo ancestral forms of storytelling, characteristic of oral cultures 
(Nikolajeva 2005; also Ong 2003). This is handy for translation workshops, because repetition allows for the text's narrative movement to be divined as the reading unfolds. Parataxis (additive structure) also minimises linkwords - specifically causal articles, conjunctions, etc. - that might only be explainable through literal translation. Finally, it allows poems to be easily broken up into episodes sharing a similar structure - and group work organised accordingly.

A first encounter with a children's poem can easily be made highly participatory. From cradle lullabies to playground songs, children's poetry is often meant to be danced to, played to, repeated and memorised. We're Going on a Bear Hunt, with hand-clapping, chanting, or actual marching, calls for repetition from the audience (of any age). Phonetic impersonation - we are asking children to mouth words they do not understand - allows the young translators-inprogress to own the sounds and rhythms, experience their work, their harshness or softness, their foreignness, around their tongues, against their teeth, in the depths of their throats and at the tips of their lips. If they dance or gesture or march, they do so to the 'tune' of words - and feel language infusing and moving their limbs. Such an experience with poetry in another language at the age of eight is not very different to the experience of poetry in one's own language at the age of one. In both cases, children appropriate sounds laden with conceptual value - some clear, some less so - in their bodies. And because children's poetry tends to be highly memorisable, the appropriation of those sounds, even in another language, is easier than with prose. One or two readings later, We're Going on a Bear Hunt will have wound its way into the bodies of the children (and the workshop leaders, who may be driven slightly mad after a few sessions); it will become their shared possession.

From then on, they will need to translate not just that poem, but the total experience of that poem.

\section{Writing the translation: becoming a poet, and a poéticien}

In this final subpart I focus on the writing process, arguing that it can align with crucial aims of literary education, by making the young translator-writer what Roland Barthes (1993) calls a poéticien, namely a poet whose poetry is inherently about poetics.

I have detailed how encounters with children's poetry in another language can be eminently pre-semantic at first. Then, at the semantic stage (the 'literal translation' stage), words can elucidate what remains of the children's uncertainties about the poem's semantic meaning. Participants might have inferred, for instance, that We're Going on a Bear Hunt is about a family crossing fields, looking for something - but what? When the bear finally appears, the children encountering the poem in the second language generally experience it as a surprise. Revealing 
that the title of the poem means 'Nous allons à la chasse à l'ours' will unlock a new dimension of meaning, at a narrative level: there was a quest all along. Gradually, such details, conceptual this time and word-focused, will clothe the poem.

Even in that process of semantic elucidation, much can be left to guesswork and rely on the deployment of lexical fields elicited by the children, erring on the side of polysemy, and keeping sounds and rhythms in mind - and body. The family reaches a 'deep, cold river' - river sounds like rivière, which French children generally guess straightaway from word and image. But the English word, we can tell them, also covers the French fleuve, wider and sea-bound. Which one is it, do you think? And what other cours d'eau, types of running water, exist? Soon the class might ponder whether to requisition here the tiny $r u$, the midsize ruisseau or the dramatic torrent, and it is easy to discuss the varied soundscapes those words afford. If it is a fleuve that is froid and profond (literal translations of 'cold' and 'deep'), then the triple $f$ can foretell the later plouf plouf, to which French children will naturally default to evoke water sounds. Yet they might elect to make it un grand ruisseau glacé, a large freezing river, rhythmically pleasing and with an gratifying triple alliteration in $g, r$ and ss. Some then turn the English splosh splash into a French gla-gla (the onomatopoeia for teeth-chattering), thus focusing on the family's sensations rather than on the splashing. And so on.

The semantic stage can involve reflection on crucial aspects of translation theory, including questions of audience. It can be useful to align with the skopos approach to translation (Vermeer 1989), namely to clarify translation choices in relation to an overarching aim. I have found that a skopos approach to translation can be implemented in ways very easily graspable for children. Simply saying to children of CM2 (in their last year of primary school), 'We're doing this translation for the CP class' (the pre-literate first-years) gives the mission a tangibility that a simple academic exercise will not. Suddenly there is an audience; it drives aesthetic considerations, and fosters translatorial responsibility. All the better if the translation can then indeed be performed to that audience.

The workshop leader, throughout this process, occupies a space in-between what educationalists after Vygotsky would characterise as that of a scaffolder, and what in any collaborative translation work one could expect of a collaborator. Certainly, the leader structures the learning experience, by standing a little outside of it. They also have crucial extra knowledge that the children do not: that of the foreign language. They are responsible for pulling together the children's suggestions, linking strands of thinking, steering the discussion, and synthesising separate points into a more general insight. Yet, because there is never a perfectly 
right answer, the workshop leader, even if they have translated the same poem with a hundred different classes, will get to class hundred-and-one not knowing how that one is going to do it. Thus, the workshop leader is always a co-translator, their propositions not necessarily wiser than the children's. This positioning is more easily achieved, I think, with poetry translation than with prose translation, because the intensely multimodal and embodied nature of encounters with children's poetry makes the translation possibilities more numerous than with prose.

As explained earlier, much of contemporary theory of poetry-translation details that practice as a commingling of writing, reading and thinking. In other words, it is a kind of learning, but a learning-by-doing; practice-based, immanent, emerging from engagement rather than from top-down instruction - in short, a typical Deweyan approach to knowledge acquisition through experiential learning (Dewey 1938). The workshop leader might explain to the children that a choice they have just made is, for instance, typical of the translatorial strategy known as 'compensation'; a basic example would be when a translator chooses to 'compensate' for the loss of an internal rhyme in one line by 'adding' an internal

Thus, the workshop leader is always a co-translator, their propositions not necessarily wiser than the children's. [...] I think, with poetry translation than with prose translation, because the intensely multimodal and embodied nature of encounters with children's poetry makes the translation possibilities more numerous than with prose rhyme elsewhere. But they might also elect not to voice this in technical terms, instead observing that it 'makes up for' the rhyme lost above. In both cases, the children will have stumbled upon compensation; whether or not it is then precisely theorised, it has happened.

I contend that through such a practice of poetry translation, theorised as the rendering of a total reading experience, conditions are gathered to cultivate an emergent sense of the literary. I say emergent from a both spatial and temporal perspective. Spatial in the sense that 'the literary' surfaces here and there throughout the activity. Sometimes its form is palpable: the written output, for instance, which is in turn analysable from the perspective of literary criticism. Most often, it is diffuse, erratic; when a child raises their hand in sudden eureka, having found what they feel is exactly 'the best words in the best order', to quote Coleridge's perhaps apocryphal definition of poetry. Aesthetic response remains, certainly, primarily unspoken: it bubbles up, involves being moved, physically and emotionally, by words, and yet perceiving that the poem is not just words-bound. 
This sense of the literary is also temporally emergent, because the encounter with a poem, followed by the writing of that encounter - the translation - is a lived and evolving thing. Pullinger talks of the slowly-developing presence of poetry, especially childhood poetry, in one's life; because of their presence inside the body and mind, and the phenomenological nature of our encounters with them, poems, she says, remain within us and grow with us (2012). As Pullinger and Whitley show (2016), poems learned, forgotten, half-remembered or misremembered have a structuring effect on one's self-narrative. A poem one has translated, namely a poem multiply appropriated, becomes an element of one's literary biography.

A corollary: for every translatorial success, there will be many failures. Words stubbornly refuse, sometimes, to be the best, in the best order. That is as much part of the literary experience as when they dutifully slot into place. Translation workshops seek to cultivate 'a posture of translation: a sensibility to the opacity of meaning, an acceptance of the uncertainty of meaning and action' (Schwimmer 2017). The inevitable frustrations of words not found and not-quiteright phrases speak, deep down, about the limits not of translation but of language, with its insufficiencies and 'shadowy zones' (Greaves and Di Stefano 2017, 59). 'I am not the master' of my language, says Laurent Jenny $(2018,13)$; that is what poetry translation reveals and exacerbates, and that is why there is literature.

Roland Barthes talks of the poéticien, the person who is not 'simply' a poet, but a theorist of their art through their art. That is not an honour he bestows lavishly. But, as I have described, poetry translation de facto brings together reading, writing, and thinking about poetry. As a class, our final product is a new poem: we have written a poem, we are a poet. That poem 'says almost the same thing' (Umberto Eco's famous expression about translation, 2006) as the source poem, so we have written a translation: we are a translator. In the process of becoming that poet-translator, we have needed to do as total a reading as could be done: we are a reader, a performer, an actor, an experiencer of this poem. And in order to render that experience, we have thought of every word, every sound, in relation to that totality. We are a thinker. All those operations do theoretical work, even if that work remains unarticulated; we have reflected on poetry in general. We did not write this reflection down; we 'only' wrote a poem. Thus, we might not be a theorist. However, the poem is there, and it captures all that reflection, that writing, that reading and that experience. Thus, we most definitely are a poéticien. 


\section{Conclusion: Même pas peur}

Much remains to be done to observe precisely what happens in translation workshops (whether or not they involve children's poetry). But I hope to have shown that there is already a lot to gather from the insights of poetics, translation theory, and the theory of children's poetry, regarding the alignment between the practice of poetry translation and some major demands of literary education. Certainly, we should not neglect the necessity, in approaches to poetry, of an analytical mindset, the lexical toolkit of literary criticism, biographical information, awareness of historical context, intertextual readings, a rigorous knowledge of poetic devices, theoretical frameworks, and so on. But that is not the whole story of poetry. Translating children's poetry with children, from a language they do not know into their own, mobilises experiential aspects of poetry unavailable in the kind of theoretical texts we can expect children to assimilate. Through this practice, the phenomenological dimension of poetry may be reclaimed. Any attempt to dichotomise form and content is revealed as futile, and felt in the most radical way: thinking along those lines simply does not work when one tries to translate poetry. 'How can you separate the inseparable?' asks Grossman rhetorically, about poetry translation $(2010,95)$. Instead, one's practice steers towards other questions - not what it means, but, as Barthes would say, how it's made - the questions of the poéticien, the poet whose poetry thinks about poetry.

Literary education is complex partly because it seeks to transmit an appreciation for aesthetics at the same time as it seeks to transmit contextual knowledge, and a knowledge of the mechanics of text; and the latter two too often undermine the former, which is more diffuse and less easily articulated. It helps, as I have detailed, to consider poetic texts as works in progress, whose reading always can (and often should) be

It helps [...] to consider poetic texts as works in progress, whose reading always can (and often should) be reactualised by writing. Literary translation, eminently, is one of the key operations by which reading gets experienced and reactualised in the world; and the practice, by necessity, does its own thinking at the time of creation. reactualised by writing. Literary translation, eminently, is one of the key operations by which reading gets experienced and reactualised in the world; and the practice, by necessity, does its own thinking at the time of creation. It is one of those exercises, preciously rare in education, that are didactically useful if and only if they are aesthetically successful.

Même pas peur!, the title of this conclusion, is one of the many ways one might translate into French the muchrepeated 'We're not scared!' of We're Going on a Bear Hunt. I end this article with a call to teachers and scholars to engage with the practice of translation in the literary 
classroom, despite the fear commonly triggered by the idea of speaking or reading another language. 'The missing element in so much writing about poetry and translation is the idea of the ludic, of jouissance, or playfulness', says Bassnett $(1988,65)$. The same can be said about much writing on language and education. With the right choice of source texts and a small amount of guidance, it does not matter if your German declensions are a bit rusty, or if you get your Russian verbs of movement mixed up (who doesn't?). Those are but little bears that can easily be run away from. A love of the target language is what matters, as well as some amount of practice with a bathroom mirror for all the confident chanting and clapping in front of a group of children. Then something literary, ludic, jouissif and playful will probably happen. Même pas peur.

\section{References}

Arizpe, E., Colomer, T., \& Martínez-Roldán, C. (2014). Visual journeys through wordless narratives: An international inquiry with immigrant children and the arrival. London: A\&C Black.

Barthes, R. (1993). Le bruissement de la langue. Essais critiques IV. Paris: Seuil.

Bassnett, S. (1998). Transplanting the seed: Poetry and translation. In S. Bassnett \& A. Lefevere (Eds.). Constructing cultures: Essays on literary translation (pp. 57-75). Clevedon: Multilingual Matters.

Bastin, G. L. (2007). Multilinguisme et tradition: un mariage de raison. Tinkuy: Boletín de investigación y debate, (4), 41-48.

Beauvais, C. (2018a). Translated into British: European Children's Literature, (In) difference and Écart in the Age of Brexit. Bookbird: A Journal of International Children's Literature, 56 (1), 1018.

Beauvais, C. (2018b). Des mots plein la bouche. Les Cahiers Pédagogiques, 549, 42-44.

Bonnefoy, Y. (1979). On the Translation of Form in Poetry. World Literature Today, 53(3), 374-379.

Briggs, K. (2017). This Little Art. London: Fitzcarraldo.

Brookman, H., \& Robinson, O. (2016). Creativity, Translation, and Teaching Old English Poetry. Translation and Literature, 25(3), 275-297.

Chamberlain, L. (1985). Gender and the Metaphorics of Translation. In L. Venuti (Ed.) (2000) The Translation Studies Reader. (pp. 314-329) London and New York: Routledge.

Coats, K. (2013). The Meaning of Children's Poetry: A Cognitive Approach. International Research in Children's Literature, 6(2), 127-142.

Davis, K. (2001). Deconstruction and Translation. Manchester: St Jerome.

Dewey, J. (1938). Experiential education. New York: Collier.

Dompmartin-Normand, C. (2016). Écrivains plurilingues et étudiants de FLE. Carnets, 7

Eco, U. (2007). Dire presque la même chose. Translated by M. Bouzaher. Paris: Grasset.

Greaves, S. \& Di Stefano, J-L. (2017). Traduire ou ne pas traduire ? L'écriture plurilingue dans un camp. Le Journal des Psychologues, 347(5), 55-60. 
Greaves, S. \& Schultze, M-L. (2012). Du gravier ou du savon dans la bouche. In C. Trimaille \& J.M. Eloy (Eds.) Carnets d'Atelier sociolinguistique (CAS), Idéologies linguistiques et discriminations (pp. 169-186). Paris: L'Harmattan.

Grossman, E. (2010). Why Translation Matters. New Haven and London: Yale University Press.

Holmes, S. (2015a). Monsters, Myths and Multilingual Creativity. Working Papers in Urban Language and Literacies, 161, 1-9.

Holmes, S. (2015b). Promoting Multilingual Creativity: Key Principles from Successful Projects. Working Papers in Urban Language and Literacies, 182, 2-17.

Houdart-Mérot, V. (2018). La création littéraire à l'université. Saint-Denis: Presses Universitaires de Vincennes.

Jakobson, R. (1959). On Linguistic Aspects of Translation. In L. Venuti (Ed.) (2000) The Translation Studies Reader (pp.113-118). London and New York: Routledge.

Jiménez, R. T., David, S., Fagan, K., Risko, V. J., Pacheco, M., Pray, L., \& Gonzales, M. (2015). Using translation to drive conceptual development for students becoming literate in English as an additional language. Research in the Teaching of English, 248-271.

Jones, F. R. (2011). The translation of poetry. In K. Malmkjaer \& K.Windle (Eds.) The Oxford Handbook of Translation Studies. Oxford Handbooks Online.

Jullien, F. (2012). L'écart et l'entre. Leçon inaugurale de la Chaire sur l'altérité. Pratiques, 253.

Kultti, A., \& Pramling, N. (2018). 'Behind the Words': Negotiating Literal/Figurative Sense When Translating the Lyrics to a Children's Song in Bilingual Preschool. Scandinavian Journal of Educational Research, 62(2), 200-212.

Lathey, G. (2016). Translating Children's Literature. Abingdon, Oxon: Routledge.

Lefevere, A. (1975). Translating Poetry: Seven Strategies and a Blueprint. Assen/ Amsterdam: Van Gorcum.

Lewis, G., Jones, B. \& Baker, C. (2012). Translanguaging: Origins and Development from School to Street and Beyond. Educational Research and Evaluation 18(7), 641-654.

Mourão, S. (2017). Picturebooks in instructed foreign language learning contexts. In C. Beauvais \& M. Nikolajeva (Eds.) The Edinburgh Companion to Children's Literature. Edinburgh: Edinburgh University Press, pp. 245-263.

Munday, J. (2009). Issues in Translation Studies. In J. Munday (Ed.) The Routledge Companion to Translation Studies (pp. 1-19). Abingdon, Oxon: Routledge.

Nabokov, V. (1955). Problems of Translation: 'Onegin' in English. In L. Venuti (Ed.) (2000) The Translation Studies Reader (pp. 1-19). London and New York: Routledge.

Nichols, U. (2014). Translators in Schools. In Other Words, 44, 16-18.

Nikolajeva, M. (2005). Aesthetic Approaches to Children's Literature: An Introduction. Oxford: Scarecrow.

Ong, W. J. (2003). Orality and literacy. Routledge.

Park, J. (2015). Learning In/Through Collaborative Poetry Translation: Documenting the Impact of Poetry Inside Out with High School-Aged English Language Learners. Journal of Language \& Literacy Education, 11(2), 134-149.

Park, J. Y., Simpson, L., Bicknell, J., \& Michaels, S. (2015). 'When It Rains a Puddle Is Made': Fostering Academic Literacy in English Learners through Poetry and Translation. English Journal, 104(4), $50-58$.

Pullinger, D. (2012). In living memory: The dying art of learning poetry and a case for revival. Changing English, 19(4), 383-393. 
Pullinger, D., \& Whitley, D. (2013). Sounding sense: The place, problems and potential of performance in poetry. Changing English, 20(2), 160-173.

Pullinger, D., \& Whitley, D. (2016). Beyond Measure: The Value of the Memorised Poem. Changing English, 23(4), 314-325.

Pullinger, D. (2017). From Tongue to Text: A New Reading of Children's Poetry. London: Bloomsbury.

Reece, A., Thompson, W., Mendy, C., \& Ardizzone, S. (2013). The spectacular translation machine. Other Words, 42, 4-9.

Reiss, K. (1971). Type, Kind and Individuality of Text: Decision Making in Translation. In L. Venuti (Ed.) (2000) The Translation Studies Reader. London and New York: Routledge, pp.160-171.

Ricoeur, P. (2004). On Translation. Translated by E. Brennan. London and New York: Routledge.

Rosen, M., \& Oxenbury, H. (1989). We're Going on a Bear Hunt. New York: Margaret K.

Rutherford, M. (2009). Poetry Inside Out: Bridging Cultures through Language. English Teaching: Practice and Critique, 8(2), 207-221.

Schwimmer, M. (2017). Beyond Theory and Practice: Towards an Ethics of Translation. Ethics and Education, 12 (1), 51-61.

Scott, C. (2012). Literary Translation and the Rediscovery of Reading. Cambridge: Cambridge University Press.

Shelley, P.B. (1821). A Defence of Poetry. Recovery from: https://www.poetryfoundation.org/articles/69388/a-defence-of-poetry

Spivak, G. C. (1992). The Politics of Translation. In L. Venuti (Ed.) (2000) The Translation Studies Reader (pp. 397-416). London and New York: Routledge.

Steiner, G. (1975). After Babel: Aspects of Language and Translation. London: Oxford University Press.

Stephen Spender Trust. (2019). Creative Translation in the Classroom and the Polish Spotlight: An evaluation of two educational outreach programmes run by the Stephen Spender Trust. Recovery from: http://www.stephenspender.org/_downloads_general/Creative_Translation_and_Polish_Spotlight_Evaluation_repo rt.pdf

Venuti, L. (1998). The Scandals of Translation: Towards an Ethics of Difference. London: Routledge.

Venuti, L. (Ed.). (2000). The Translation Studies Reader. London and New York: Routledge.

Vermeer, H. J. (1989). Skopos and Commission in Translational Action. In L. Venuti (Ed.) (2000) The Translation Studies Reader (pp. 221-232.). London and New York: Routledge.

Wilson, E. (2017). Translator's Note. Homer's The Odyssey. New York: WW. Norton.

How to cite this paper:

Beauvais, C. (2019). An Emergent Sense of the Literary: Doing Children's Poetry Translation in the Literature Classroom. Journal of Literary Education, (2), pp. 8-28. doi: 10.7203/JLE.2.14827 